Johan Strang

\title{
The Rhetoric of Nordic Cooperation: From the Other Europe to the Better Europe?
}

\section{Introduction}

Despite the recent surge in rhetoric of (New) Nordicness, the term "Nordic cooperation" continues to evoke a mixture of feelings among most people in the region. On the one hand, the term refers almost unconditionally positively to the special kinship associated with the idea of Norden as a cultural, linguistic, and historical community, and as such it involves a strong sense of normative obligation. On the other hand, "Nordic cooperation" implies a sense of impotence and irrelevance, relating to the primacy of the transatlantic security regime and the European economic and political frameworks. A similar tension is also present in scholarship, which tends to build on pre-determined narratives of Nordic cooperation either as a remarkable success in creating a transnational community, or as a series of failures to formalise cooperation in economic or security policy. ${ }^{1}$ This chapter explores the political struggles to define Nordic cooperation from the 1950s until today. It will show that the tension between obligation and impotence has been an enduring part in the rhetoric of Nordic cooperation, but also that the criteria for success and failure, and indeed the meaning of Norden has changed through time.

The chapter analyses the debates of the annual sessions of the Nordic Council (NC), focusing primarily on periods of formative importance in negotiating the tasks and limitations of official Nordic cooperation: the first years of the NC after its establishment in 1952, the (collapsed) plans for a Nordic customs union around 1960 and again a decade later, the EU debates during the first half of the 1990s, and the rise of "the Nordic brand" in the new millennium. A key feature at all these junctures was the omnipresence of "Europe" in the background of the discussions. "Europe," "European cooperation," "the European Economic Community (EEC)," or, since the late 1980s and 1990s, "European integration" and "the European Union (EU)," were for a long time all seen as competitors to Nordic cooperation, legitimising it and pushing it forward. At the same time

1 For a recent discussion of this literature see my "Introduction: The Nordic model of transnational cooperation," in Nordic Cooperation: A European region in transition, ed. Johan Strang (London: Routledge, 2016); Anne Elizabeth Stie and Jarle Trondal, eds., "Rediscovering Nordic cooperation," special issue, Politics and Governance 8 (2020).

Ә OpenAccess. (C 2022 Johan Strang, published by De Gruyter. (cc) BY This work is licensed under the Creative Commons Attribution 4.0 International License. https://doi.org/10.1515/9783110730104-006 
European integration also constituted a massive gravitational force whose movements had huge repercussions for Nordic cooperation even before Denmark joined the EEC in 1973 and Finland and Sweden joined the EU in 1995. ${ }^{2}$

Following the terminology of Reinhart Koselleck, "Nordic cooperation" and "European integration" can be analysed as "asymmetric counter-concepts." 3 The rhetoric of Nordic cooperation and European integration was never an antithetical juxtaposition of two equally distinguishable units. Instead, Nordic cooperation was defined through an indeterminate other, associated with a number of vague and usually quite negative attributes. "Europe" served as the supranational, utopian, bureaucratic, capitalist, conservative, or elitist other, which was used to portray Nordic cooperation as democratic, pragmatic, progressive, and socially responsible. Yet, it would be misleading to claim that the discussions at the NC were marked by a general anti-European sentiment; on the contrary, the NC attracted internationally oriented MPs, many of whom were decidedly in favour of European cooperation already in the 1950s. The point of the asymmetrical juxtaposition was to negotiate the relationship between the Nordic and the European frameworks, to bolster the idea of Norden as a cultural and political community, as well as to legitimise the NC as an institution.

The rhetoric of Nordic cooperation and European integration was also asymmetric in the sense that the one (Norden) in most conventional definitions was understood as part of the other (Europe). The relation between Norden and Europe was under constant negotiation, but the 1990s represented a major turning point. The Maastricht Treaty and the European Union were debated across the region, initially reigniting the historical opposition between Nordic cooperation and European integration. Eventually, however, Norden was absorbed by Europe, not least as Finland and Sweden joined the EU in 1995. In the new millennium, therefore, many of the old narratives of Nordic cooperation had lost their foundation. Gradually, however, a new rhetoric of Nordicness was invented, which relied less on the European other, but also less on notions of transnational cooperation.

2 Thorsten Borring Olesen and Johan Strang, "European challenge to Nordic institutional cooperation: past, present and future," in Nordic cooperation: A European region in transition, ed. Johan Strang (London: Routledge, 2016), doi:10.4324/9781315755366-2; Bo Stråth, "The Swedish image of Europe as the other," in Europe and the other and Europe as the other, ed. Bo Stråth (Wien: PIE Lang, 2010).

3 Reinhart Koselleck, “The historical-political semantics of asymmetric counter-concepts," in Futures past: on the semantics of historical time, trans. Keith Tribe (1979; New York: Columbia, 2004), 155-91; see also Kirill Postoutenko and Kay Junge, eds., Asymmetrical concepts after Reinhart Koselleck: Historical semantics and beyond (Bielefeld: transcript Verlag, 2011). 
This chapter focuses on the development of two related tropes in the rhetoric of Nordic cooperation. The first half of the chapter explores how the idea of Nordic cooperation as a more democratic and "popular" form of international collaboration than European integration emerged during the first decades of the $\mathrm{NC}$, and how this trope was turned into a celebration of the "flexibility" of Nordic cooperation, and of the close, trusting, personal connections between leading Nordic politicians in the integrating Europe of the post-Cold War period. The second half of the chapter analyses the emergence of the idea of Nordic cooperation as evolving primarily around a culturally, linguistically, and historically founded community and describes how the turn towards branding in the new millennia transformed Nordic culture and welfare into examples of European excellence that were used on the global markets. Together, the two parts of the chapter make the argument that there in the new millennium seems to be more use for "the Nordic" as a pre-existing natural quality of the peoples and products of the region, than of Norden as a political community of five nations, which is why the recent wave of Nordic rhetoric has so far failed to bolster Nordic cooperation.

\section{Nordic cooperation and the Nordic Council}

The history of Nordic cooperation is usually dated back to the bourgeoning trans-Nordic networks among professionals and voluntary associations in the wake of the Scandinavist movement at the end of the $19^{\text {th }}$ century. Of special importance were the Nordic Lawyers' meetings, arranged regularly since 1872 with the aim of harmonising legislation and creating a common Nordic legal culture. ${ }^{4}$ The NC, founded in 1952, grew out of the gradual intensification of the political relations between the Nordic countries during the inter-war period, intense debates on Nordic unification during the Second World War, as well as a general push for regional cooperation and alignment in Western Europe in the emerging Cold War setting. ${ }^{5}$ The immediate post-war period saw many Nordic initiatives: a

4 Ruth Hemstad, Fra Indian Summer til nordisk vinter: Skandinavisk samarbeid, skandinavisme og unionsoppløsningen (Oslo: Akademisk publisering, 2008); Pia Letto-Vanamo and Ditlev Tamm, “Cooperation in the field of law," in Nordic Cooperation: A European region in transition, ed. Johan Strang (London: Routledge, 2016), doi:10.4324/9781315755366-5.

5 Jan A. Andersson, “1950-talet: tid att så - tid att skörda,” in Norden i sick-sack: Tre spårbyten inom nordiskt samarbete, ed. Bengt Sundelius and Claes Wiklund (Stockholm: Santérus, 2000); Franz Wendt, Cooperation in the Nordic Countries: achievements and obstacles (Stockholm: Nordic Council, 1981), 33-36. 
Nordic Culture Commission was founded in 1946 and discussions on a Nordic customs union began in 1947. Following the Prague coup in February 1948, there were also prestigious negotiations on a Scandinavian defence union, which ultimately broke down in January 1949 when Norway (and then Denmark) decided to join NATO.

According to a common interpretation, the NC was founded as a compensation for the failure of the Scandinavian defence union, and precisely like the defence union - and the Scandinavist movement a century before - it was primarily a Danish-Swedish initiative. Hans Hedtoft, the Danish Social Democratic leader and Prime Minister for the periods 1947-50 and 1953-55, served as a political driving force, and the Swedish Conservative MP and lawyer Nils Herlitz drafted the founding documents. It has been speculated that Hedtoft's interest in Nordic cooperation was motivated by an urge to associate his party with the success of the Swedish Social Democrats, and certainly, the Nordic labour movements had already established strong relations before the war. ${ }^{6}$ But Nordism was undoubtedly a catch-all ideology at the time, with the Nordic Associations attracting high membership figures across the political spectrum in Denmark and Sweden. Among Norwegian conservatives and farmers there was, however, a lingering suspicion that Nordic cooperation was a tool for Danish or Swedish imperialistic ambitions, and a majority of non-socialist MPs voted against the establishment of the NC in the Norwegian parliament. Also, in Iceland the NC was met with some opposition connected both to economic considerations and to their recent independence from Denmark. Restricted by its relation to the Soviet Union, Finland was unable to join until 1955, but the founding documents left a space open for the easternmost Nordic country. ${ }^{7}$ Thus, the geographical extension of the NC's definition of Norden was undisputed from the start and has largely remained so until today, despite some discussions of Baltic membership in the early 1990s.

6 The Joint Committee of the Nordic Social Democratic Labour Movement was founded in 1932 on the basis of cooperation that had taken place since 1886. See e.g. Andersson, "1950-talet"; Pauli Kettunen et al., "The Nordic Model and the rise and fall of Nordic cooperation," in Nordic Cooperation: A European region in transition, ed. Johan Strang (London: Routledge, 2016), doi:10.4324/9781315755366-4; Mirja Österberg, “Norden' as a transnational space in the 1930s: negotiated consensus of 'Nordicness' in the Nordic Committee of the labour movement," in Labour, unions and politics under the North Star: the Nordic countries, 1700-2000, ed. Mary Hilson, Silke Neunsinger, and Iben Vyff (New York: Berghahn, 2017).

7 Andersson, “1950-talet”; Peter Stadius, "Hundra år av nordism,” in Meningen med föreningen: Föreningarna Norden 100 år, ed. Henrik Wilén (Copenhagen: Föreningarna Nordens Förbund, 2019); Svein Olav Hansen, Vennskap og kjennskap i 100 år: Foreningen Norden 1919-2019 (Oslo: Gyldendal, 2020); Wendt, Cooperation, 35-38. 
The annual sessions of the NC take place in the parliament building of a Nordic capital on a rotating basis. Eighty-seven delegates chosen among the national members of parliament gather for three to six days of meetings and debates on Nordic issues. ${ }^{8}$ The NC has never had legislative power. Its main role is to give recommendations to the five governments, the normative power of which have varied through time. Even though the NC nominally is an organisation for inter-parliamentary cooperation representatives from the governments, including the Prime Ministers, also take part in the NC sessions. This lends the debates a parliamentary character, where delegates hold governments accountable for their activities. ${ }^{9}$ This aspect of the NC was strengthened in 1971, when the governments established their own organisation for Nordic cooperation, the Nordic Council of Ministers (NCM), which also has an independent budget (today an annual of €128 million).

Traditionally, the sessions begin with a general debate, which, formally, concerns an annual report on Nordic cooperation put forward by the presidium of the NC, but which in practice turns into a discussion on the state of Nordic cooperation in general and the most pressing issues of the time. ${ }^{10}$ To be sure, focusing on the debates at the NC sessions in order to target the rhetoric of Nordic cooperation involves some methodological challenges. There is an obvious risk, not only that the significance of the rhetoric of Nordicness and Nordic cooperation is exaggerated, but also that the phrase "Nordic cooperation" is used differently in the NC sessions to how it is used in the national parliaments or public debates. The material is particularly likely to contain an overrepresentation of sentimental Nordism, and the delegates tend to equate "Nordic cooperation" with the NC and NCM, overlooking other venues for interaction between the

8 Iceland has 7 seats and the four larger Nordic countries have 20 each. Two of the Finnish and two of the Danish seats have, since 1970, been reserved for representatives from Åland and the Faroe Islands. Since 1984 an additional two Danish seats have been allocated to delegates from Greenland. Due to the small size of the Icelandic parliament, the sessions in Reykjavik usually take place in another location. In addition to the annual sessions, the NC has, since the end of the 1980s, arranged shorter thematic sessions on a semi-regular basis, usually at a venue outside of the capitals.

9 Of the four key features of a parliament listed by Ihalainen, Ilie, and Palonen, the NC fulfils two: deliberation and representation. The other two features, responsibility and sovereignty, are not fulfilled. See Pasi Ihalainen, Cornelia Ilie, and Kari Palonen, "Parliament as a conceptual nexus," in Parliament and parliamentarism: A comparative history of a European concept, ed. Pasi Ihalainen, Cornelia Ilie, and Kari Palonen (New York: Berghahn, 2016).

10 There have, of course, been numerous changes to the agenda and choreography of the NC sessions throughout the years, but the first day(s) of the sessions have usually remained reserved for more general discussions. 
five countries. With these caveats in mind, there is arguably no better material for exploring the broad variety and complexity of speech acts associated with the term "Nordic cooperation," as the NC sessions confront both political and national variations of this rhetoric with each other.

\section{From democracy to flexibility: Nordic cooperation and its supranational other}

\section{Democracy as national sovereignty}

One of the most enduring tropes at the Nordic Council has undoubtedly been that of democratic Nordic cooperation and its supranational and federal European other. Clearly, the NC was not established with any supranational ambitions, but in the 1950s, when the aims and purposes of the NC were still under negotiation, there were many animated discussions on Nordic cooperation and national sovereignty. At the very first sessions in Copenhagen in 1953, the issue surfaced in the form of a debate on the legacy of $19^{\text {th }}$ century Scandinavism. Celebrating the establishment of the NC, Hans Hedtoft argued that the Scandinavist movement had an unfortunately poor reputation as it was remembered particularly for its failure to produce a united Scandinavian kingdom or a more formal union. Its main achievement, Hedtoft argued, was in bringing the Scandinavian peoples together and making war between Nordic countries impossible. ${ }^{11}$ This idolisation of the Scandinavist movement provoked a response from the leader of the Norwegian Conservative Party, C. J. Hambro, who explained that his opposition towards the establishment of the NC had not been based on any anti-Nordic sentiments, but on a historically conditioned suspicion against Swedish and Danish great power ambitions. "The word union,” Hambro explained, "whether it refers to the Kalmar Union or something else, does not ring well in Norwegian ears." 12 This Norwegian criticism forced Hedtoft to clarify

11 Hans Hedtoft (Denmark, Social Democrat), Nordisk råd 1. session, København 1953 (København: J. H. Schultz, 1953), 94-100. I refer to the debates at the Nordic Council with the name of the speaker (country, party), Nordisk råd (Nordic Council), and the city and year of the meeting. The protocols are available in the so called Blue book series, published at various locations and publishers throughout the years 1953-2011, after which they have been made available online at https://www.norden.org/en/information/past-sessions (accessed September 16 2021). All translations from the Nordic languages are mine.

12 C. J. Hambro (Norway, Conservative), Nordisk råd, København 1953, 143-144. On the Norwegian relation to the Scandinavist movement, see Hemstad's chapter in this volume. 
that in referring to Scandinavism he was not proposing that the NC would lead the way towards a Nordic union. Rather, in carrying the spirit of Scandinavism, the NC had learned the lesson that cooperation requires respect for the distinctive character of each nation: "the aim of the NC is agreement, not unity," Hedtoft concluded. ${ }^{13}$

Caution was undoubtedly called for, not only with regard to the Norwegian sceptics, but also against the background of the recent failure of the defence union and the different foreign policies pursued by the Nordic countries in the Cold War setting. Indeed, foreign policy was excluded from the agenda of the NC from the start, which in itself contributed to the wide agreement that "Nordic cooperation" had to refrain from supranational and federal aspirations. Following Hedtoft's example, a standard argument was that "cooperation" (dk. samarbejde, f. yhteistyö, isl. samstarf, n. samarbeid, sv. samarbete) required equal and sovereign partners, and that the breakup of the former Danish and Swedish empires and the independence of the five Nordic nations had enabled peaceful coexistence and collaboration in the region. ${ }^{14}$ Initially, this was also interpreted as a strength. Comparisons with European initiatives like the Council of Europe (1949), the European Coal and Steel Community (1951), and Benelux cooperation initiatives were common in order to articulate the advantages of the pragmatic and democratic Nordic model of cooperation. The Danish Conservative Ole Bjørn Kraft, for example, argued in 1954, "Whereas the Council of Europe is founded on the idealistic aim of creating a United States of Europe, Nordic cooperation has grown organically out the independence of the five peoples: it is practically oriented and rejects calls for unification based on dogmatic principles or theoretical speculation." 15 Similarly, in the following year, Hedtoft proudly stated that the NC had not wasted time and energy on fruitless discussions between federalists and functionalists. Instead it had proceeded soberly and pragmatically with the issues at hand, and by paying due respect to the sovereignty of the participating nations. This approach, according to Hedtoft, now served as an example for Europe. ${ }^{16}$

13 Hans Hedtoft (Denmark, Social Democrat), Nordisk råd, København 1953, 167-169.

14 Magnús Jonssón (Iceland, Conservative Independence Party), Nordisk råd, København 1953, 79; Tage Erlander (Sweden, Social Democrats), Nordisk råd, Stockholm 1955, 43; Bent Røiseland (Norway, Liberal Venstre), Nordisk råd, Stockholm 1955, 57.

15 Ole Bjørn Kraft (Denmark, Conservative), Nordisk råd, Oslo 1954, 32.

16 Hans Hedtoft (Denmark, Social Democrat), Nordisk råd, Stockholm 1955, 38; see also Hedtoft, Nordisk råd, Oslo 1954, 19. 
The first years of the NC is often celebrated as a "golden epoch" of Nordic cooperation, ${ }^{17}$ but they were certainly not seen as such by contemporaries. To be sure, the period produced a passport union (1952-58), a common labour market (1954), and a social security convention (1955), but these agreements were never central to the debates at the $\mathrm{NC}$ - they had been initiated already before the establishment of the NC and were largely uncontroversial. ${ }^{18}$ Instead, the discussions were marked by the shadow of the failed defence union on the one hand, and by difficult and divisive negotiations on a Nordic trade deal on the other. Whereas the Danish representatives aimed for a full customs union that also included agricultural products, the Swedes and Norwegians feared that their farmers would be outrivalled. Swedish scepticism was mitigated by the prospect of an expanded market for their thriving industry, which in turn only exacerbated the Norwegian concerns. ${ }^{19}$ At the NC, the Norwegian sceptics often associated their resistance with a concern for national sovereignty. Jon Leirfall from the Agrarian (Centre) Party, for example, believed that the advocates of the customs union were aiming at turning the NC into a supranational parliament. Leirfall argued that "Danish and Swedish dreams have often proved to be Norwegian nightmares," pointing also to the historically conditioned Norwegian scepticism against the word "union."20 The Norwegian liberal Arthur Sundt, in turn, stressed that there were limits to how far Norway could go in political integration only fifty years after gaining sovereignty. He also feared that the NC was aiming too high, and that the success of Nordic cooperation in the field of law and social policy should not be scoffed at just because Europe provided tempting examples of economic integration. ${ }^{21}$

Significantly enough, the proponents of the Nordic trade deal did not object to this framing of supranationality as essentially un-Nordic. Instead, they played along with the rhetoric of democratic Nordic cooperation and federalist European integration, trying to convince the Norwegian sceptics that there were no supranational ambitions in the Nordic plans. The Swedish Prime Minister Tage Er-

17 See e.g. Sundelius and Wiklund, Norden i sick-sack, 18.

18 Wendt, Cooperation in the Nordic Countries, 188-89 and 213-21.

19 Juhana Aunesluoma, Vapaakaupan tiellä: Suomen kauppa- ja integraatiopolitiikka maailmansodasta EU-aikaan (Helsinki: SKS, 2011), 176 - 80; Mikael af Malmborg, Den ståndaktiga nationalstaten: Sverige och den västeuropeiska integrationen 1945-1959 (Lund: Lund University Press, 1994), 338-341; Bo Stråth, Nordic industry and Nordic economic cooperation (Stockholm: Almqvist \& Wiksell, 1978); Vibeke Sørensen, "Nordic Cooperation: A Social Democratic alternative to Europe," in Interdependence versus integration: Denmark, Scandinavia and Western Europe 1945-1960 (Odense: Odense University Press, 1995).

20 Jon Leirfall (Norway, Centre Party), Nordisk råd, Oslo 1954, 197.

21 Arthur Sundt (Norway, Liberal), Nordisk råd, København 1956, 81 and 204-207. 
lander, for example, ensured that national sovereignty and democracy remained priorities, and contrasted this with how the Benelux customs union had been pushed through by the countries' respective governments. The Nordic countries had chosen a more democratic path, Erlander argued, involving the parliaments in the discussion, thus building their cooperation on solid ground. ${ }^{22}$

\section{Nordic cooperation and its accelerating other}

Intimately connected to these discussions of democracy, sovereignty, federalism, and supranationality were notions of temporality and the speed of development. If the members of the NC in the early 1950s boasted that Nordic cooperation was "ahead" of Europe, things changed with the complex European free trade negotiations in the latter half of the decade. Already in 1955, when the so-called Inner Six (Belgium, France, Germany, Italy, Luxembourg and the Netherlands) agreed upon the Messina plan for economic integration, a worry emerged within the NC that Nordic cooperation was being outpaced. "It seems as if the decisiveness is greater in Europe," the chairman of the Swedish liberals Bertil Ohlin complained. ${ }^{23}$ At this point, however, there was still wide agreement that the slowness of Nordic cooperation was a consequence of the lack of supranationality, and as such a price worth paying: it was "characteristic of the Nordic peoples to build slowly but solidly," which would "serve to reduce frictions in the long run." ${ }^{24}$ Just a couple of years later, however, when the Treaty of Rome (1957) established the European Economic Community (EEC), there was already a widespread fear that Nordic cooperation was being left behind. While EEC membership was still out of the question, a British proposal for a larger European free trade area was welcomed by the Nordic countries. ${ }^{25}$ As the 1958 sessions were postponed from the spring to the autumn in anticipation of the EEC's reaction to the British proposal, impatience and self-criticism grew within the NC. Ohlin, for example, feared that the pace and practices of Nordic cooperation had become a handicap rather than an advantage: "Perhaps, making comprehensive studies and investigations before every decision serves only to amplify the problems." 26 A month after the 1958 sessions, France pulled out of the

22 Tage Erlander (Sweden, Social Democrat), Nordisk råd, København 1956, 59.

23 Bertil Ohlin (Sweden, Liberal), Nordisk råd, København 1956, 41.

24 Rolf Edberg (Sweden, Social Democrat), Nordisk råd, København 1956; Finn Moe (Norway, Labour Party), Nordisk råd, Stockholm 1955, 54.

25 af Malmborg, Den ståndaktiga nationalstaten, 301.

26 Bertil Ohlin (Sweden, Liberal), Nordisk råd, Oslo 1958, 187. 
FTA negotiations, which left the UK and the Scandinavian countries stranded without a deal with the EEC. As a response, "the outer seven" (the three Scandinavian countries, UK, Switzerland, Austria and Portugal) established the European Free Trade Association (EFTA) in the summer of 1959.27

EFTA effectively put an end to the plans for a tightly integrated Nordic customs union and the NC sessions in November 1959 were again held in a gloomy atmosphere, with many speakers bemoaning the fact that the NC had failed with its key initiative. ${ }^{28}$ The Prime Ministers, in turn, argued that EFTA was a success as it created a Nordic common market, but admitted that Nordic cooperation had been overrun by European developments. The Danish Prime Minister H.C Hansen, for example, bemoaned the fact that the Nordic tradition of advancing step by step - so successful in forging the social security convention - had proven at odds with the rules of the game on this particular occasion. But he also emphasised that the prolonged process had served its purpose of forging broad Nordic unanimity: even the Norwegian opposition to the Nordic customs union was in favour of EFTA. ${ }^{29}$

A lasting legacy from the prolonged customs union negotiations was undoubtedly the cementation of "Nordic cooperation" as inherently anti-federalist. Indeed, it was even codified as such in the Helsinki Treaty, signed in March 1962. The aim of the treaty was to signal Nordic unity at a point when external forces seemed to pull the region apart: the Soviet Union was, following the Berlin Crisis, increasing its pressure on Finland, while Denmark and Norway were - along with the UK - considering EEC membership. ${ }^{30}$ The result was a treaty with vague and non-committing formulations, which was met with disappointment at the

27 Thorsten Borring Olesen, "EFTA 1959-1972: an exercise in Nordic cooperation and conflict," in Regional cooperation and international organizations: The Nordic model in transnational alignment, ed. Norbert Götz and Heidi Haggrén (London: Routledge, 2009). Finland was unable to join EFTA in 1960 because of Soviet and UK opposition, but after effective lobbying by Finland in the east and Sweden in the west, Finland became an associate member in 1961 (Finn-EFTAagreement).

28 Bertil Ohlin (Sweden, Liberal), Nordisk råd, Stockholm 1959, 42; Karl-August Fagerholm (Finland, Social Democrat), Nordisk råd, Stockholm 1959, 46.

29 H. C. Hansen (Denmark, Social Democrat), Nordisk råd, Stockholm 1959, 59-60.

30 Johan Vibe, "Norden - et samarbeide nedenfra?," in Hva skjedde med Norden? Fra selvbevissthet til rådvillhet, ed. Iver B. Neumann (Oslo: Cappelen, 1992); Claes Wiklund, "1962 års Helsingforsavtal - den första heltäckande nordiska samarbetstraktaten,” in Norden i sick-sack: Tre spårbyten inom nordiskt samarbete, ed. Bengt Sundelius and Claes Wiklund (Stockholm: Santérus, 2000). 
1962 sessions. ${ }^{31}$ The Prime Ministers, however, defended it as "an important declaration of intent," and the Finnish Foreign Minister Ahti Karjalainen even argued that the treaty was "a perfect reflection of Nordic cooperation, bringing the countries together despite the differences in foreign policy orientations." ${ }^{32}$

The un-Nordicness of supranational federalism was also a key element in the negotiations for a Nordic economic union around 1970. The ambitious socalled Nordek plan included, among other things, a customs union and a common investment bank. ${ }^{33}$ Considerations had, again, to be paid to the different security policies of the Nordic nations, and to the potential Danish -and Norwegian - membership in the EEC. Accordingly, the governments were careful not to propose any limitations of national sovereignty. The rhetoric of Nordic cooperation and European integration served this purpose well. At the 1969 sessions, the Danish Social Democratic leader Jens Otto Krag recognised that Nordek required new institutions, but emphasised that it was important to stick to "the voluntary and consensual form of Nordic cooperation" and "to avoid majority decision-making procedures like in the EEC." ${ }^{34}$ The Norwegian Centre Party Prime Minister, Per Borten, similarly emphasised that Nordic cooperation had to stay true to its "democratic ideals." ${ }^{35}$ Nordek would undoubtedly have been a rather strange construction: a comprehensive economic union without supranational institutions. It was, however, the only path available, on the one hand because of the different security policies pursued by the Nordic countries, and on the other hand because Nordic cooperation was defined as inherently antifederal.

If references to Europe, during the late 1950s and early 1960s, served the purpose of rallying Nordic cooperation in order to keep pace with European developments, the Nordek negotiations were even more strongly marked by the asymmetry between Nordic cooperation and European integration: it was clear that the former had to adapt to the pace of the latter. The Danish government

31 Gunnar Helén (Sweden, Liberal), Nordisk råd, Helsingfors 1962, 59-60; Kjell Bondevik (Norway, Christian People's Party), Nordisk råd, Helsingfors 1962, 77.

32 Tage Erlander (Sweden, Social Democrat), Nordisk råd, Helsingfors 1962, 81; Einar Gerhardsen (Norway, Labour), Nordisk råd, Helsingfors 1962, 70; Ahti Karjalainen (Finland, Agrarian), Nordisk råd, Helsingfors 1962, 197.

33 See Jan Hecker-Stampehl, ed., Between Nordic ideology, economic interests and political reality: New perspectives on Nordek (Helsinki: Finnish Society of Letters, 2009); Lasse Sonne, NOR$D E K$ - A plan for increased Nordic economic cooperation and integration (Helsinki: Finnish Society of Letters, 2007).

34 Jens Otto Krag (Denmark, Social Democrat), Nordisk råd, Stockholm 1969, 65.

35 Per Borten (Norway, Centre Party) Nordisk råd, Stockholm 1969, 100. 
launched the Nordek plan when De Gaulle had vetoed British and Danish membership in the EEC for a second time in 1967: there was a temporary European standstill, which the Nordic countries sought to utilise. The Danish Social Democratic leader Jens Otto Krag urged the Nordic leaders forward arguing that the experience a decade ago had proven that it was dangerous to wait, and the Swedish liberal leader Bertil Ohlin stated that he wished the NC could lock the Prime Ministers in an Arctic hotel to forge the deal. ${ }^{36}$

The reasons for the failure of Nordek have been subject to much discussion, but a key factor was the Danish-Finnish disagreement on the relation between Nordic cooperation and Europe. As pointed out by Danish historian Thorsten Borring Olesen, the normative appeal of Nordic cooperation was that it could be - and often was - used as way for the Nordic countries to influence and direct each other. ${ }^{37}$ During the Nordek debates, Krag tried to pull his neighbours closer to the EEC, claiming that "the Nordic union is a desirable and perhaps even necessary step towards something larger: Europe,” while the Finnish Prime Minister Mauno Koivisto, out of considerations of Finland's special relations to the Soviet Union, tried to keep the whole of Norden outside of the EEC by insisting on the "intrinsic value" of Nordek. ${ }^{38}$ These different views came to a head when it gradually became clear that Denmark intended to follow the UK into the EEC, which ultimately provoked Finland to withdraw from the project, causing its collapse. ${ }^{39}$

\section{Flexible cooperation within Europe}

The Single European Act in 1986 and the Maastricht Treaty in 1992, which transformed the European community into the European Union (EU), provoked an intense debate on the future of Nordic cooperation. By this time the rhetoric of Nordic cooperation, as something that was unique, pragmatic, and democratic, had

36 Jens Otto Krag (Denmark, Social Democrat), Nordisk råd, Stockholm 1969, 64; Bertil Ohlin (Sweden, Liberal), Nordisk råd, Stockholm 1969, 82.

37 See Olesen and Strang, "European challenge," 32; Thorsten Borring Olesen and Poul Villaume, Dansk udenrigspolitisk historie V: I blokopdelningens tegn (Copenhagen: Gyldendal, 2006), $545-51$.

38 Jens Otto Krag (Denmark, Social Democrat), Nordisk råd, Stockholm 1969, 66; Mauno Koivisto (Finland, Social Democrat), Nordisk råd, Stockholm 1969, 102; Koivisto, Nordisk råd, Reykjavik 1970, 85.

39 See e.g. Aunesluoma, Vapaakaupan tiellä, 231-39; Hecker-Stampehl, Between Nordic ideology, 13-17. 
become part of the liturgy at the annual NC sessions. In 1989, in typical fashion, the Swedish Prime Minister Ingvar Carlsson applauded how Nordic cooperation brought together not only the governments, but also the peoples in Norden, that it was voluntary in character and respected the sovereignty of the nations. ${ }^{40} \mathrm{An}$ increasing number of delegates, however, started to challenge this rhetoric of Nordic exceptionality, arguing that Nordic cooperation had to adapt to the pace of an accelerating European integration. At the 1988 NC sessions, the Danish Prime Minister Poul Schlüter warned his Nordic colleagues that "the European train" was on the move, and that the rediscovered dynamism in the EC was something that could not be ignored by the NC. ${ }^{41}$ Most vocal was the Swedish conservative leader Carl Bildt, who, from 1987 to 1994, relished presenting temporalized arguments that urged the Nordic countries to get involved in European integration. He argued that "when history is accelerating in Europe, the clock must not stand still in Norden," warning also that "in stagnating, the NC was risking what it had accomplished." ${ }^{22}$ Doing so, Bildt alluded to established notions of the slowness and impotence of Nordic cooperation, as well as to its asymmetrical and reactive relation to European integration. Indeed, one of Bildt's leading themes was to call for a shift towards thinking in terms of "Norden within Europe" rather than "Norden or Europe."43

In the escalating EC/EU debates it was particularly the opponents of Nordic EU membership who were most eager to sustain the rhetoric of Nordic cooperation as a democratic alternative to the federal European other. ${ }^{44}$ Criticising the transfer of sovereignty from the national legislatures to Brussels and the "democratic deficit" of the EU apparatus, they celebrated Nordic cooperation as a more democratic model of international cooperation. Olof Johansson, the leader of the Swedish Centre Party, for example, argued that Nordic cooperation was unique in being mellanfolkligt ("inter-popular," meaning transnational or international at a non-elite level) in the true sense of the word, and claimed, in

40 Ingvar Carlsson (Sweden, Social Democrat), Nordisk råd, Stockholm 1989, 88; Páll Péturson (Iceland, Progressive), Nordisk råd, København 1991, 54.

41 Poul Schlüter (Denmark, Conservative), Nordisk råd, Oslo 1988, 132.

42 Carl Bildt (Sweden, Conservative), Nordisk råd, Stockholm 1989, 69; Nordisk råd, Mariehamn 1989, 34; Nordisk råd, Reykjavik 1990, 95-96.

43 Carl Bildt (Sweden, Conservative), Nordisk råd, Helsingfors 1987, 76; Nordisk råd, Helsingfors 1992, 62; Nordisk råd, København 1991, 57. See also Carl Bildt, Hallänning, svensk, europé (Stockholm: Bonniers, 1991).

44 Carsten Schymik, "European Antifederalists," in Northern Europe and the future of the EU: Nordeuropa und die Zukunft der EU, ed. Helge Høibraaten and Jochen Hille (Berlin: Intersentia, 2011). 
1991, that Nordic cooperation could serve as a model for countries in Eastern Europe who, in recently having regained their independence, were hardly keen on new supranational constraints. ${ }^{45}$

On the pro-European side, which included the governments, it became a key task to frame not only European integration, but also supranationality and federalism in a more positive light. The standard argument was that in binding the European nations together, supranational European integration had been crucial in creating peace in Europe. Some, like the Norwegian Foreign Minister Thorvald Stoltenberg, also claimed that "binding cooperation" actually was in the interest of small states like the Nordic ones. With the creation of the EU, France and Germany were no longer able to pursue their foreign policies without taking smaller European nations into account. ${ }^{46}$ Supranationalism and binding international cooperation were also presented as inevitable parts of post-Cold War globalisation. Most explicit was, again, the Swedish Prime Minister Carl Bildt, who, notably tired of the sovereignty debate, claimed that "[t]here is no place for Robinson Crusoe politics in the modern world." He argued that if Crusoe had been sovereign on his deserted island, he was certainly very happy to share some of it when Friday came along. ${ }^{47}$

Significantly enough, the governments reserved their propensity for binding and supranational cooperation for the European framework. When it came to Nordic cooperation, they continued to emphasise the right of every nation to pursue its own interests. The Norwegian Prime Minister Gro Harlem Brundtland, for example, argued that while Finland, Norway, and Sweden would pursue the EU negotiations separately, the governments would constantly keep each other informed using the unique informal networks that exist between the Nordic countries. According to Brundtland, Nordic cooperation had not been created through formal decisions or treaties; rather, its defining feature and special strength was the multitude of informal networks that existed between politicians, bureaucrats, unions, and businesses in the different countries, and the cultural and historical affinity based on shared values. ${ }^{48}$ In this way, the governments gradually redeployed the rhetoric of Nordic cooperation and its supranational European other: the non-binding and democratic character of Nordic cooperation evolved into an argument about a pre-existing affinity between the Nordic governments, and the flexibility and efficiency of their informal relations. If the previous argu-

45 Olof Johansson (Sweden, Centre Party), Nordisk råd, Mariehamn 1989, 54; Nordisk råd, Mariehamn 1991, 88; Marianne Samuelsson (Sweden, Green Party), Nordisk råd, Mariehamn 1989, 53. 46 Thorvald Stoltenberg (Norway, Labour Party), Nordisk råd, Århus 1992, 52.

47 Carl Bildt (Sweden, Conservative), Nordisk råd, Stockholm 1994, 77.

48 Gro Harlem Brundtland (Norway, Labour Party), Nordisk råd, Århus 1992, 39 \& 44. 
ment had been that the Nordic countries could not unite because of their different security or economic interests, the argument now was that the Nordic countries did not need to unite because they shared so many networks and values.

This gradual redescription of Nordic cooperation coincided with a series of reforms which increased the role of the prime ministers and decreased the funding of the NCM. ${ }^{49}$ Critics were swift to notice that the celebration of the unique informal networks were used to cushion or even conceal a dismantling of Nordic institutional cooperation. As president of the Nordic Council in 1994, the Swedish Social Democrat Sten Andersson expressed his concerns that Prime Ministers were blocking the NC and the parliamentarians' ability to influence decisionmaking and that Nordic cooperation was developing a democratic deficit like the EU. ${ }^{50}$ The Swedish Prime Minister Carl Bildt responded that while the governments were improving formal institutions, unique informal networks were efficient and something that the Nordic countries should be proud of. ${ }^{51}$

Informality and flexibility replaced democracy and sovereignty as the main characteristic of Nordic cooperation. In 1995, the new Swedish Prime Minister Ingvar Carlsson proudly stated that Nordic cooperation was part of his everyday routine: "Among the Nordic Prime Ministers, we phone each other when we need to, in order to check our positions - it is fast and easy." 52 At this point, the rhetoric of informal Nordic cooperation was used particularly against the idea of formalising Nordic cooperation on EU matters. One of the most determined voices was the Finnish Prime Minister Paavo Lipponen, who repeatedly testified to the intimate informal relations between the three Nordic EU members while vehemently rejecting the idea of creating a "Nordic block." 53 In his federal vision of the EU, there were no place for permanent alliances. Aiming at taking Finland to "the core of the EU," Lipponen was also reluctant to associate with Denmark and Sweden, whose governments still struggled with significant domestic scepticism against particularly the Economic and Monetary Union. ${ }^{54}$

49 Olesen and Strang, "European challenge," 35-36; Bjørn Otto Sverdrup, "Europeisering som de-institusjonalisering - nordisk politisk samarbeid i endring," in Europa i Norden: Europeisering av nordisk samarbeid, ed. Johan P. Olsen and Bjørn Otto Sverdrup (Oslo: Tano Aschehoug, 1998).

50 Sten Andersson (Sweden, Social Democrat), Nordisk råd, Stockholm 1994, 56-57.

51 Carl Bildt (Sweden, Conservative), Nordisk råd, Stockholm 1994, 72-73.

52 Ingvar Carlsson (Sweden, Social Democrat), Nordisk råd, Reykjavik 1995, 63.

53 Paavo Lipponen (Finland, Social Democrat), Nordisk råd, København 1996, 49; Nordisk råd, Stockholm 1999, 51; Nordisk råd, Reykjavik 2000, 49.

54 Richard Brander, Finland och Sverige i EU: tio år av medlemskap (Helsingfors: Schildts 2004), 65-75; Tapio Raunio and Teija Tiilikainen, Finland in the European Union (London: Frank Cass, 2003), 150. 
As the majority of the Nordic countries were members of the EU, the rhetoric of Nordic cooperation and its supranational and federal European other became a way of expressing the special informal bonds between the Nordic countries within a larger European framework. Clearly, it was an attempt to make a virtue of necessity. In a more cynical interpretation, however, it was also a way of reducing Nordic cooperation to a matter of informal contacts and relations in the shadow of European integration, and of legitimising or even disguising budgetary cuts in the NCM. The rhetoric of the unique democratic, pragmatic, and informal Nordic cooperation served as a handy narrative against strengthening Nordic institutional cooperation. It provided the governments with an opportunity to frame themselves as pro-Nordic while at the same time refusing to commit themselves to more formalised cooperation.

In the new millennia, there was a somewhat surprising return of the Scandinavist dream of a formalised Nordic union, associated primarily with the Swedish historian Gunnar Wetterberg and his 2010 yearbook of the Nordic Council calling for a United Nordic Federation..$^{55}$ Despite receiving quite a lot of public attention across the region, the politicians at the NC politely ignored Wetterberg's proposal as a valuable source of inspiration. ${ }^{56}$ The former Norwegian foreign minister Thorvald Stoltenberg's report with 13 proposals for strengthening Nordic security and defence cooperation made a more significant impact on the debates. ${ }^{57}$ Some observers have claimed that the circle became complete, as the discussion had returned to the same theme that had started Nordic political cooperation in the wake of the Second World War. It was an opportunity to make good for the failure of the defence union in $1948 .{ }^{58}$ It is, however, important to emphasise that the Stoltenberg report did not propose any supranational elements, that it did not address the divisive NATO question, and that it was celebrated for its pragmatism and flexibility. ${ }^{59}$ Indeed, as the Nordic countries in the

55 Originally proposed in an opinion article in Dagens Nyheter in 2009, the NC promptly asked Wetterberg to develop the idea in book form. Gunnar Wetterberg, The United Nordic Federation (Copenhagen: Nordic Council, 2010).

56 Asta Ragnheidur Johannesdottir (Iceland, Social Democrat), Nordisk råd, Reykjavik 2010, 36; Bente Dahl (Denmark, Social Liberal), Nordisk råd, Reykjavik 2010, 50).

57 Thorvald Stoltenberg, Nordic cooperation on foreign and security policy (Oslo: Norwegian Government Security and Service Organisation (G.S.S.O.), 2009), https://www.regjeringen.no/ globalassets/upload/ud/vedlegg/nordicreport.pdf.

58 Bengt Sundelius and Claes Wiklund, "Quo vadis? Tretton insikter om Norden," in Norden sett inifrån: Det fjärde spårbytet, ed. Bengt Sundelius and Claes Wiklund (Stockholm: Santérus, 2017), 312.

59 At the NC, see e.g. Espen Barth Eide, Nordisk råd, Helsingfors 2012, (https://www.norden. org/en/event/64th-session-2012) speech 142. 
wake of the Stoltenberg report have strengthened their foreign and security policy cooperation, the rhetoric of the successful informal Nordic cooperation prevails, while proposals for a more formalised framework for foreign and security policy cooperation has fallen on deaf ears. ${ }^{60}$

\section{From distinctiveness to distinction: Nordic cooperation and its conservative and capitalist other}

\section{The Nordic cultural community}

Closely related to the notion of Nordic cooperation as a particularly democratic and "popular" form of transnational cooperation, is the idea of Norden as a unique community of shared languages, cultures, and values. ${ }^{61}$ This has also been a central trope in the rhetoric at the Nordic Council, serving as a legitimation of the NC itself, and as part of the motivations for various cooperation initiatives. The first sessions of the NC in 1953 were, understandably, marked by much sentimental rhetoric of Nordic kinship and unity. According to Hans Hedtoft, for example, the NC was "the latest shoot on the tree whose roots run deep in the Nordic peoples." 62 Comparisons to Europe were common, and a standard argument was that if "Europe" had succeeded in forging cooperation schemes and trade deals, the Nordic countries should also be able to do so given the exceptional cultural ties between the countries. Launching the Nordek initiative in 1968, for example, the Danish Liberal Prime Minister Hilmar Baunsgaard argued that the affinity between the Nordic peoples had "the potential for developing into something more concrete," while his foreign minister Poul Hartling claimed

60 There have been repeated proposals to include foreign and security policy in the institutional framework of the NCM, and in 2014 Thorvald Stoltenberg himself suggested the establishment of a Nordic defence commission. Thorvald Stoltenberg, Nordisk råd, Stockholm 2014, speech number 292, https://www.norden.org/en/node/18902.

61 See e.g. Iver B. Neumann, "Tre Innfallsvinkler til Norden: Kulturfelleskap, oppdemming for stormaktspolitikk, regionbygging," in Hva skjedde med Norden, ed. Iver B. Neumann (Oslo: Cappelen, 1992).

62 Hans Hedtoft (Denmark, Social Democrat), Nordisk råd, København 1953, 95 and 101; Vilhelm Buhl (Denmark, Social Democrat), Nordisk råd, København 1953, 78; Nils Herlitz (Sweden, Conservative), Nordisk råd, København 1953, 86. 
that the region, by virtue of the special kinship between its peoples, had "outstanding pre-conditions for economic integration." ${ }^{63}$

More common, however, than using culture and identity as a lever for deeper integration was to refer to the cultural and linguistic community as a way to strengthen the rhetoric when Nordic cooperation had experienced a backlash. ${ }^{64}$ In the wake of the collapsed customs union negotiations, the Norwegian Christian Democrat Erling Wikborg argued that in language and culture there was more that tied the Nordic countries together than there was pulling them apart, while the Danish Conservative Ole Bjørn Kraft bemoaned the Nordic failures in defence policy and trade, but urged the NC to take its third chance in the field of culture. ${ }^{65}$ When the Nordek deal broke down in 1970 and Denmark was moving towards the EEC, the Danish Social Democratic Prime Minister Jens Otto Krag called upon the NC to strengthen its focus on areas that remained outside the Rome Treaty, most notably the field of culture. ${ }^{66}$ His Finnish colleague from the Centre Party, Ahti Karjalainen, even claimed that "Finland has always seen culture as one of the most important fields of Nordic cooperation." ${ }^{67}$ Indeed, it was often those who, for various reasons, had toppled Nordic integration schemes who felt obliged to praise Nordic cultural unity and the rhetoric was also often backed up financially by initiatives and investments to further cooperation in the field of culture and education. After the collapse of the customs union the NC established the Literature Prize in 1962 and a Nordic Culture Fund in 1966. Similarly, the breakdown of the Nordek negotiations led to a new culture treaty in 1971 and a significant rise in funding for the Nordic Culture Fund. ${ }^{68}$

63 Hilmar Baunsgaard (Denmark, Social Liberal), Nordisk råd, Oslo 1968, 62; Poul Hartling (Denmark, Liberals), Nordisk råd, Oslo 1968, 87.

64 Nils Andrén, "Det officiella kultursamarbetet i Norden,” Den Jyske Historiker 69-70 (1994): 213-27; Anna Kharkina, From Kinship to Global Brand: The discourse on culture in Nordic cooperation after World War II (Stockholm: Acta Universitatis Stockholmiensis, 2013); Bengt Sundelius, Managing Transnationalism in Northern Europe (Boulder: Westview Press, 1978), 88.

65 Erling Wikborg (Norway, Christian People’s Party), Nordisk råd, København 1961, 54. Ole Bjørn Kraft (Denmark, Conservative), Nordisk råd, Stockholm 1964, 64.

66 Jens Otto Krag (Denmark, Social Democrat), Nordisk råd, København 1971, 60 -61.

67 Ahti Karjalainen (Finland, Centre Party), Nordisk råd, København 1971, 82.

68 Kharkina, From Kinship to Global Brand, 57-70; Anne-Marie Mai, "Dreams and realities: The Nordic Council Literature Prize as a symbol for the construction of Nordic cultural cooperation," in Nordic Cooperation: A European region in transition, ed. Johan Strang (London: Routledge, 2016), doi:10.4324/9781315755366-6. 
Of course, from today's horizon it would perhaps be easy to argue that the aim of the rhetoric of cultural unity and Nordic cultural cooperation was to create a culturally (and even racially) homogenous Norden. In some structural sense, this might be the case, but it is important to remember that in the 1960s and 70s, cultural policy was not primarily associated with national conservatism; rather, it formed a key part of the toolbox of progressive Social Democrats who wanted to counter marketisation and make culture available for larger sections of society. ${ }^{69}$ It was seen as a pivotal vehicle for democratising society and building the welfare state, and in this sense, Nordic cooperation in culture was not merely a compensation for failures in other areas, but part of a progressive programme for modernising society.

In fact, the use of culture as a rhetorical scapegoat was more pertinent in connection with the reforms of the NC/NCM structure after Finland and Sweden joined the EU in 1995. For example, although Carl Bildt had warned in 1990 that the NC would be "reduced to a forum of cultural manifestations" if it refused to take European integration seriously, he claimed that the common cultural identity was the very core of Nordic unity when he was Prime Minister in $1994 .{ }^{70}$ In his opening speech at the 1995 sessions, the Danish Prime Minister Poul Nyrup Rasmussen emphasised the importance, at this critical juncture, of strengthening the Nordic community and its shared values and cultures. ${ }^{71}$ Naturally, concerns were raised that the governments were using cultural cooperation in order to compensate for, or even conceal, the cuts in other sectors of the Nordic budget. ${ }^{72}$ However, as the future of the NC/NCM structure was cast in doubt, there was no opposition against singling out culture as a key focus area of Nordic cooperation. In a period of Europeanisation, cultural cooperation re-emerged as a tool for legitimising Nordic cooperation in general and the NC/NCM apparatus in particular. It provided the governments with an alibi against accusations of not taking Nordic cooperation seriously.

The explicit othering of Europe - or other regions - was rare in this rhetoric of Nordic cultural unity and cooperation. However, the compensatory logic of investing in culture in the wake of failures in trade arguably contributed to a selfpropelling narrative according to which Nordic cooperation was primarily about

69 Peter Duelund, ed., The Nordic Cultural Model (Copenhagen: Nordic Cultural Institute, 2003); see e.g. Kulturrådet, Ny kulturpolitik: nuläge och förslag (Stockholm: Allmänna förlaget, 1972), 66.

70 Carl Bildt (Sweden, Conservative), Nordisk råd, Reykjavik 1990, 96; Nordisk råd, Stockholm 1994, 73.

71 Poul Nyrup Rasmussen (Denmark, Social Democrat), Nordisk råd, Reykjavik 1995, 37-38. 72 Tora Aasland Houg (Norway, Socialist), Nordisk råd, Århus 1992, 83. 
culture and identity, while European integration was primarily a matter of trade and economy. Indeed, it has often been claimed that the Nordics have approached European integration mainly as a matter of trade and economy, while remaining rather reserved about European identity building projects. ${ }^{73}$

\section{Nordic cooperation and the welfare state}

The European other was more pertinent in the discussions on the Nordic welfare state. The idea that the Nordic countries share social and welfare political ambitions had been a central part of the rhetoric of Nordic distinctiveness, since, perhaps, the 1930s. This rhetoric had often been encouraged by foreign interest and modelled on foreign examples. ${ }^{74}$ At the Nordic Council, Nordic welfare exceptionalism was construed particularly by othering European conservatism and capitalism, which, as shown by Swedish historians Bo Stråth and Lars Trägårdh, formed central tropes in Swedish anti-EEC rhetoric from the 1960 s onwards. ${ }^{75}$ At the NC, this rhetoric was most pronounced among delegates from the left wing, who already in the 1960s and 70s described the EEC as an "unholy Roman Empire" dominated by capitalistic interests threatening the solidaristic Nordic wel-

73 Caroline Howard Grøn, Peter Nedergaard, and Anders Wivel, "Mr. Svensson Goes to Brussels: Concluding on the Nordic Countries and the European Union," in The Nordic Countries and the European Union, ed. Caroline Howard Grøn, Peter Nedergaard, and Anders Wivel (London: Routledge, 2015); Mary Hilson, The Nordic Model: Scandinavia since 1945 (London: Reaktion Books, 2008), $134-44$.

74 Nils Edling, The Changing Meanings of the Welfare State: Histories of a key concept in the Nordic countries (New York: Berghahn, 2019); Pauli Kettunen, "The transnational construction of national challenges: the ambiguous Nordic model of welfare and competitiveness," in Beyond welfare state models: transnational perspectives on social policy, ed. Pauli Kettunen and Klaus Petersen (Cheltenham: Edward Elgar, 2011); Klaus Petersen, "National, Nordic and trans-Nordic: transnational perspectives on the history of the Nordic welfare states," in Beyond welfare state models: transnational perspectives on social policy, ed. Pauli Kettunen and Klaus Petersen (Cheltenham: Edward Elgar, 2011); Klaus Petersen \& Carl Marklund, "Return to sender: American images of the Nordic welfare states and Nordic welfare state branding," European Journal of Scandinavian Studies 43 (2013): 245-57, doi:10.1515/ejss-2013-0016.

75 Bo Stråth, "Poverty, Neutrality and welfare: Three key concepts in the modern foundation of the myth of Sweden," in Myth and memory in the construction of community: Historical patterns in Europe and beyond, ed., Bo Stråth (Wien: PIE Lang, 2000); Bo Stråth, “The Swedish image”, 374-75; Lars Trägårdh, "Sweden and the EU: welfare state nationalism and the spectre of 'Europe"' in European integration and national identity: The challenge of the Nordic states, ed. Lene Hansen and Ole Wæver (London: Routledge, 2002). 
fare states. ${ }^{76}$ It would, however, be incorrect to reduce the idea of Nordic welfare exceptionalism to a left-wing construction. Liberals like Bertil Ohlin were also wary of sharing social policy ambitions with continental Europe, while the Norwegian Conservative leader Kåre Willoch, in the wake of the Nordek breakdown, argued that Norden was a natural region for cooperation because of "the natural fellowship of the Nordic countries, based upon common culture and traditions, and somewhat similar visions for developing our welfare societies."77 The Nordic welfare state served as a legitimation of Nordic cooperation across the political spectre.

In social policy discourse, the asymmetrical comparisons to Europe were often temporalised, but contrary to the discussions on economic integration, welfare was a field where the Nordics considered themselves as more progressive than their European others, at least until the turning point of the 1990s. This pertained both to the idea of the Nordic social systems as more advanced than the European ones, and to the achievements of Nordic cooperation in this area - for example, the social security convention of 1955. Even pro-Europeans like the Danish Liberal Prime Minister Hilmar Baunsgaard used temporalised rhetoric to claim that the Nordic countries by virtue of their "achievements in social welfare, democracy and freedom" had much to offer Europe. ${ }^{78}$

There were, however, also internal Nordic dynamics to this temporalised rhetoric. As shown by welfare state historians Pauli Kettunen, Klaus Petersen, and others, Nordic cooperation served as an arena for sharing best practices, and it was not unusual that the countries competed to claim the most advanced social legislation. ${ }^{79}$ Being ahead - usually the privilege of Sweden - was to a significant degree a matter of having the power of determining the "Nordic" solution to a particular problem. In a Nordic latecomer like Finland, by contrast, the rhetoric of Nordicness signified, in the words of Pauli Kettunen, "a future code and normative standard of Finnish society." ${ }^{80}$ At a time when social policy

76 Einar Olgeirsson (Iceland, Socialist), Nordisk råd, Helsingfors 1962, 97-98; C.H. Hermansson (Sweden, Socialist), Nordisk råd, København 1971, 100; Aksel Larsen (Denmark, Socialist), Nordisk råd, København 1971, 149.

77 Bertil Ohlin (Sweden, Liberal), Nordisk råd, Helsingfors 1957, 101; Kåre Willoch (Norway, Conservative), Nordisk råd, Helsingfors 1972, 95.

78 Hilmar Baunsgaard (Denmark, Social Liberal), Nordisk råd, Reykjavik 1970, 76.

79 Kettunen et al. "The Nordic Model”; Petersen, "National, Nordic and trans-Nordic."

80 Pauli Kettunen et al., "The Nordic Model”, 77-78; Pauli Kettunen, "The Nordic Welfare State in Finland," Scandinavian Journal of History 26, no. 3 (2001): 234, doi:10.1080/ 034687501750303864; see also Stefan Nygård and Johan Strang, "Conceptual Universalization and the Role of the Peripheries," Contributions to the History of Concepts 12, no. 1 (1 June 2017): 55-75, doi:10.3167/choc.2017.120105. 
modernisation was thought of as a linear and almost deterministic development, "the Nordic" became synonymous to "the most advanced" and even "the future".

Curiously, however, the rhetoric of Nordic cooperation could also have a conservative function. A pertinent example was the discussions on the Swedish marriage law reforms at the $\mathrm{NC}$ in the early 1970s which aimed at strengthening the position of wives, making it easier for couples to divorce each other, and improving the legal position of unmarried couples. This provoked conservatives at the NC to mobilise the rhetoric of Nordic cooperation against the proposed reform, claiming that Sweden was abandoning a century-long tradition of Nordic legal harmonisation. According to the Norwegian Conservative Berte Rognerud, for example, the Swedish reform represented not only a radical break with western traditions and conceptions of marriage. It was also a violation of the Helsinki Treaty, as Sweden intended to transform its legislation without paying due respect to the situation in other Nordic countries. ${ }^{81}$ Carl Lidbom, the legal advisor in Olof Palme's Social Democratic cabinet, responded that as a result of Danish EEC membership "harmonisation was no longer a realistic ambition for Nordic cooperation," but he also expressed fears that the calls for harmonisation were slowing down the development of the welfare state. ${ }^{82}$ Prime Minister Palme made the point even more forcefully, arguing that "Nordic cooperation must never become a conservative hindrance for a country to move forward along the path of progress."83 Among legal scholars, the debates on the Swedish marriage law are often referred to as a turning point in the history of Nordic legal cooperation: the point at which Sweden single-handedly abandoned the aim of Nordic legal harmonisation. ${ }^{84}$ It is more accurate, however, to view it as a clash between two different understandings of Nordic cooperation: a progressive one according to which Nordic cooperation was a forum where the laggards could learn from the more advanced, and a deliberative one where Nordic cooperation was a forum for negotiating common solutions. In temporal terms, the question was whether the Nordic countries would synchronise around the most advanced or around an average speed of development. ${ }^{85}$

81 Berte Rognerud (Norway, Conservative), Nordisk råd, Oslo 1973, 125-126.

82 Carl Lidbom (Sweden, Social Democrat), Nordisk råd, Oslo 1973, 80 - 83.

83 Olof Palme (Sweden, Social Democrat), Nordisk råd, Oslo 1973, 122.

84 Letto-Vanamo and Tamm, “Cooperation in the field of law," 104-105; Kjell Åke Modéer, "Comparative critical legal studies: US and the Nordic countries - a review article," Retfærd 37 (2014): 128.

85 Helge Jordheim and Einar Wigen, "Conceptual Synchronisation: From Progress to Crisis," Millennium: Journal of International Studies 46, no. 3 (June 2018): 421-39, https://doi.org/ 10.1177/0305829818774781. 
The welfare state was in the 1960s and 70s seen as both a product of Nordic cooperation and as somethig that legitimised it, but it was not until the 1990s that "the Nordic welfare state" became a key concept at the NC sessions - conspicuously at a time when it no longer self-evidently represented the future. ${ }^{86}$ The end of the Cold War pulled the rug from under the rhetoric of the Nordic middle way between socialism and capitalism, and the economic recession in Finland and Sweden raised serious questions about the viability of a large public sector and comprehensive social services. Moreover, the acceleration of European integration and the ensuing EU debates across the region challenged the relationship between Norden and its asymmetrical European other.

At the NC sessions it was, again, particularly the left-wing members who saw European integration as a threat to both Nordic cooperation and the Nordic welfare state. They claimed that the EU was a neoliberal design that played into the hands of big corporations, capital, and business, and argued that the Conservatives were using the EU as a tool for dismantling the Nordic welfare state. ${ }^{87}$ Some, like the Norwegian socialist Kjellbjørg Lunde, even tried to mobilise intensified Nordic cooperation as a pro-welfare state alternative to the EU. ${ }^{88}$ For the Social Democrats European integration was a divisive issue. However, a popular argument, especially among Swedish Social Democrats, was that Nordic cooperation could become a vehicle for exporting the welfare state to Europe - that Europe could become more Nordic, at least as much as Norden became more European. ${ }^{89}$ The Finnish Social Democrat Erkki Tuomioja, in turn, was less buoyant and referred ironically to "the admirable self-confidence by which Ingvar Carlsson has professed the aim of realising Margaret Thatcher's nightmare of a wel-

86 Pauli Kettunen, "The conceptual history of the welfare state in Finland," in The changing meanings of the welfare state: Histories of a key concept in the Nordic countries, ed. Nils Edling (New York: Berghahn, 2019); Bo Stråth, "Den nordiska modellen. Historisk bakgrund och hur talet om en nordisk modell uppstod," Nordisk tidskrift för vetenskap, konst och industri (1993), 55-61. Moreover, as pointed out elsewhere in this volume, the 1990s was also when the "Nordic welfare state" was canonised in academic discourse through the Danish social scientist Gøsta Esping-Andersen's book Three Worlds of Welfare Capitalism (Cambridge: Polity Press, 1990). 87 Lars Werner (Sweden, Socialist), Nordisk råd, Oslo 1988, 148; Claes Andersson (Finland, Socialist), Nordisk råd, Mariehamn 1989, 35-36.

88 Kjellbjørg Lunde (Norway, Socialist), Nordisk råd, Oslo 1993, 73. The Finnish Centre Party politician and devoted EU opponent Paavo Väyrynen also proposed a Nordic community as an alternative to the EU. Pertti Joenniemi, "Finland in the new Europe: A Herderian or Hegelian concept," in European integration and national identity: The challenge of the Nordic states, ed. Lene Hansen and Ole Wæver (London: Routledge, 2002), 206.

89 Mats Hällström (Sweden, Social Democrat), Nordisk råd, København 1991, 100; Ingvar Carlsson (Sweden, Social Democrat), Nordisk råd, Stockholm 1994, 66. 
fare Europe." ${ }^{\prime 0}$ Conservatives across the region were overwhelmingly in favour of European integration, which also translated into a somewhat ambivalent attitude towards the legacy of the (Social Democratic) Nordic welfare state. The Danish Prime Minister Poul Schlüter, for example, argued that Nordic EC membership could have something important to offer Europe, "in their societal model, even if it has some deficiencies." ${ }^{91}$ Most explicit in their anti-Nordic rhetoric were libertarians in the Danish and Norwegian Progressive Parties, who saw themselves as representatives of a liberal wave sweeping across Europe that eventually would emancipate also the Nordic countries from socialist authoritarianism. The Norwegian Progressive Party chairman Carl I. Hagen professed in 1991 that "The epoch of strong states, high taxes and bureaucracy is over," calling also for the NC to be shut down, as it was a Cold War construction that had overplayed its role..$^{92}$ The fate of the Nordic welfare state and Nordic cooperation were intimately related to each other in these early 1990s discussions on European integration.

\section{The New Nordic brand}

The EC/EU debates of the early 1990s were clearly a turning point in the rhetoric of Nordic cooperation. It was the first time that doubts over, and even criticism of, the idea of Norden as a distinct region were heard at the NC. As the asymmetrical opposition to European integration dissolved, there was a growing confusion as to the meaning and purpose of Nordic cooperation. The professed antiNordists, however, remained few, and the rhetoric of Nordic kinship continued to figure in celebratory speeches at the $\mathrm{NC}$, but the discussions were undoubted-

90 Erkki Tuomioja (Finland, Social Democrat), Nordisk råd, Mariehamn 1991, 93.

91 Kimmo Sasi (Finland, Conservative), Nordisk råd, Mariehamn 1989, 74-75; Poul Schlüter (Denmark, Conservative), Nordisk råd, Reykjavik 1990, 6.

92 Carl I. Hagen (Norway, Progressive), Nordisk råd, Reykjavik 1990, 89; Nordisk råd, København 1991, 62; Nordisk råd, Mariehamn 1991, 42; Nordisk råd, Oslo 1993, 65; Pia Kjærsgaard (Denmark, Progressive), Nordisk råd, København 1991, 147; Nordisk råd, Århus 1992, 67; Pål Atle Skjervengen (Norway, Progressive), Nordisk råd, Reykjavik 1990, 66. The right-wing populists changed their position on the EU following the Maastricht Treaty 1992 (and their view on the welfare state in the early 2000s). See Ann-Cathrine Jungar and Anders Ravik Jupskås, "Populist Radical Right Parties in the Nordic Region: A New and Distinct Party Family?,” Scandinavian Political Studies 37, no. 3 (September 2014): 215-38, doi:10.1111/1467-9477.12024; Jens Rydgren, "Explaining the Emergence of Radical Right-Wing Populist Parties: The Case of Denmark,” West European Politics 27, no. 3 (May 2005): 474-502, doi:10.1080/0140238042000228103. 
ly marked by a sense of marginalisation of "the Nordic." It did not take long, however, before culture and welfare returned as key features of the debates at the NC, but as a significantly transformed rhetoric that relied little on the European other, and even less on Nordic cooperation. Instead, "the Nordic" was reinvented as a global brand, as a trademark to be used on global markets.

According to Swedish historian Anna Kharkina, the 2005 report Norden - en global vinderregion (Norden - a global winner region) was particularly significant in introducing the concept of branding to the NC/NCM apparatus. Commissioned by the NCM and produced by the Danish think tank Mandag Morgen, the report painted a picture of globalisation as simultaneously a threat and an opportunity for the Nordic countries. ${ }^{93}$ Threatened by intensified global competition, the success of the Nordic countries in different international rankings, such as the World Competitiveness Index, was a source for optimism. According to the report, the region shared a number of culturally embedded values that formed crucial ingredients in the recipe for a successful innovation economy, and thus Mandag Morgen urged the Nordic governments to redefine the aim and purpose of Nordic cooperation towards branding the region on the basis of these distinctive Nordic values and the cultural legacy of the region. ${ }^{94}$

The idea of "Norden as a global winner region" captured the imagination of the politicians at the NC, who were eager to capitalise on the improved global reputation of the Nordic countries. In 2006, the NC devoted the Prime Ministers' summit to a discussion of the report. The Norwegian Prime Minister Jens Stoltenberg did raise a warning that the Nordics should not attempt to become global winners at the expense of others. ${ }^{95}$ But the general sentiment among the Nordic leaders was that the Nordics had succeeded in balancing a free market with social security, and as such provided an example for others to learn from. The Finnish Prime Minister Matti Vanhanen proudly noted that "the awareness of the Nordic model has increased lately, not only within the region itself. The Nordic brand is spreading around the world. Our success in the international rankings has given the Nordic countries well-deserved attention."96 The Danish Prime Minister Anders Fogh Rasmussen in turn, praised the Danish model of "flexicur-

93 Mandag Morgen, Norden som global vinderregion: På sporet af den nordiska konkurrencemodel (Copenhagen: Nordic Council and Nordic Council of Ministers, 2005); Kettunen, "The transnational construction."

94 Mandag Morgen, Norden som global vinderregion, 81-84.

95 Jens Stoltenberg (Norway, Labour Party), Nordisk råd, København 2006, 58.

96 Matti Vanhanen (Finland, Centre Party), Nordisk råd, København 2006, 39. 
ity" and called for joint Nordic branding initiatives to strengthen the position of Nordic countries in the global markets. ${ }^{97}$

The Nordic welfare state had throughout the history of the NC been thought of as a model for other countries to learn from, but there was something new in this turn to region branding. The Mandag Morgen report can be related to the contestation of the Social Democratic ownership of the welfare state, which had started already in the 1990s both in politics and in research. ${ }^{98}$ As the origins of the welfare state were traced further back in history, the welfare state was decoupled from social democracy and became an expression of a common Nordic cultural legacy which every political party could claim to represent - albeit in different ways. The cultural turn played into the hands of the xenophobic right, for whom the welfare state was threatened by globalisation and immigration, but also the Conservatives claimed to represent the Nordic model in a series of political campaigns that framed them as "the true labour parties" and "the new welfare parties." ${ }^{99}$ Even the Social Democrats embraced the cultural turn proclaiming the values of the welfare state as the natural values of the Nordic nations: they were Nordic values - "nordiska värderingar." Intended as a move to monopolise the welfare state, the redescription of the welfare state from politics to culture served the contrary purpose of stretching the concept, making it available for a broader variety of political actors. Indeed, as pointed out by the Swedish political historian Jenny Andersson, the appeal to national values and unity was a way of silencing conflicts around change. ${ }^{100}$

Crucially, however, the cultural turn and the rhetoric of "Nordic values" also disconnected the welfare state from Nordic cooperation, putting the emphasis on Nordicness alone. The Danish historian Mads Mordhorst, for example, has argued that nation branding transformed the idea of the nation from a social construct to an ontological object with an essence. Branding was a nationalism for

97 Anders Fogh Rasmussen (Denmark, Liberal), Nordisk råd, Reykjavik 2005, 2; Nordisk råd, København 2006, 74.

98 Lønning, Ojala, Stavad, NC 2005, 31-40; Peter Baldwin, The Politics of Social Solidarity: Class Bases of the European Welfare State, 1875-1975 (Cambridge: Cambridge University Press, 1990), doi:10.1017/CBO9780511586378; Øystein Sørensen \& Bo Stråth, ed., The Cultural Construction of Norden, (Oslo: Scandinavian University Press), 1997.

99 See the individual chapters in Nils Edling, ed., The changing meanings of the welfare state: histories of a key concept in the Nordic countries (New York: Berghahn, 2019); Carl Marklund, "The Nordic Model on the Global Market of Ideas: The Welfare State as Scandinavia's Best Brand,” Geopolitics 22, no. 3 (July 2017): 623-39, doi:10.1080/14650045.2016.1251906. See also Hilson and Hoctor in this volume.

100 Jenny Andersson, The Library and the Workshop: Social Democracy and Capitalism in the Knowledge Age, (Stanford: Stanford University Press, 2010), 43-61. 
the new competition state, bringing together the call for economic competitiveness and the quest for cultural belonging in a period of neoliberal globalisation. ${ }^{101}$ As such, the nation became less an internal concern of creating a common horizon of meaning and values, and more an external strategy for promoting the interest of the nation on the global market. The rhetoric of Nordicness served this purpose well as it built a bridge between the competitive and modern Nordic model and the primordial Nordic culture and values on which it allegedly was based. Nordic cooperation was no longer part of the narrative. ${ }^{102}$

Something similar also happened to the role of culture in Nordic cooperation. If cultural cooperation previously had served identity building purposes, strengthening connections across the region, "the Nordic" was now turned into an attribute or quality of the cultural products of the region. The task of the NC/NCM framework was no longer to promote dialogue or interaction between cultural institutions or independent cultural actors in the different Nordic countries, but to take successful initiatives from the creative industries and promote them on the global markets. The turn towards branding redefined the purpose of the NCM, who compensated for its marginalisation as a political forum by accentuating its role as an advertising agency. In the years that followed the Mandag Morgen report the NCM streamlined its institutions and redirected funds to grant schemes and a series of region branding projects, like the New Nordic Food programme analysed by Lily Kelting in this volume. ${ }^{103}$ The rhetoric of Nordic cooperation and European integration was replaced by a rhetoric of "New Nordicness," where not only the asymmetrical European other, but also the ambition of forging a transnational Nordic community, had lost currency.

By way of paradox, however, this essentialisation of "the Nordic" did not entail a return of "the European other." As suggested by British IR scholar Christopher Browning, the idea of something distinctively Nordic was, since the end of the Cold War, undermined by a melding of Nordic and European norms and val-

101 Peter Duelund, “Nordic Cultural Policies: A Critical View,” International Journal of Cultural Policy 14, no. 1 (February 2008): 18-19, doi:10.1080/10286630701856468; Mads Mordhorst, "Nation branding and nationalism," in Nationalism and the Economy: Explorations into a Neglected Relationship, ed. Stefan Berger and Thomas Fetzer (Budapest: Central European University Press, 2019).

102 Kettunen et al, "The Nordic Model and the rise and fall of Nordic cooperation."

103 Duelund, "Nordic cultural policies"; Kharkina, From kinship to global brand; Mathias Danbolt, "New Nordic Exceptionalism: Jeuno JE Kim and Ewa Einhorn's The United Nations of Norden and Other Realist Utopias," Journal of Aesthetics \& Culture 8, no. 1 (January 2016): doi:10.3402/jac.v8.30902; Kharkina, From Kinship to Global Brand, 113-162. 
ues. ${ }^{104}$ Indeed, when Matti Vanhanen in 2006 praised the global success of the Nordic model, he also emphasised that "Europe and Norden share a similar attitude towards the soft sectors, to social security and sustainable development." ${ }^{05}$ Defined less in terms of social democracy and more through global competitiveness and international rankings, the Nordic model was transformed from an alternative to a superior implementation of a common European theme. When the Nordic ceased to signify "the other Europe," it was reinvented as "the better Europe."106

\section{Conclusions}

This chapter has revisited the debates on the purpose and nature of Nordic cooperation at the Nordic Council, not to revise the traditional narratives of Nordic cooperation, but with the aim of exploring how these narratives were created in the first place. Strategic security concerns and economic interests undoubtedly pulled the Nordic countries apart, making more binding forms of cooperation, let alone a formalised supranational Nordic federation, impossible. In the wake of failures in security and trade, cooperation was directed towards the fields of culture and welfare, which gradually became defining features of Nordic cooperation itself. More often than not, this rhetoric of Nordic cooperation was based on an asymmetrical juxtaposition to European integration. Nordic cooperation was framed as democratic and "popular," anchored in shared cultural legacies and a common social political vision, in contrast to the supranational, conservative, and trade-focused European integration.

The rhetoric of Nordic cooperation was never static, it was constantly adjusting to a mutating relationship to Europe. Particularly when, in the 1990s, the opposition between Norden and Europe was dissolved, the traditional narratives of Nordic cooperation had to be redescribed. The democratic and popular character of Nordic cooperation was turned into a matter of flexibility, anchored in deep

104 Christopher S. Browning, 'Branding Nordicity: Models, Identity and the Decline of Exceptionalism', Cooperation and Conflict 42, no. 1 (March 2007): 27-51, doi:10.1177/0010836707073475. 105 Matti Vanhanen (Finland, Centre Party), Nordisk råd, København 2006, 39-40. See also e. g. Inge Lønning (Norway, Conservative), Nordisk råd, Reykjavik 2005, 18-19.

106 On the notion of the Nordic region and Nordic cooperation as "the other Europe," see for example, Barry Turner and Gunilla Nordquist, The Other European Community: Integration and Cooperation in Northern Europe (Houndmills: Palgrave, 1982); or more recently, Caroline Howard Grøn, Peter Nedergaard, and Anders Wivel, eds., The Nordic Countries and the European Union: Still the Other European Community? (London: Routledge, 2015). 
and trusting personal relations between leading politicians in the region, while Nordic cultural and welfare exceptionalism were reinvented as key aspects of a "New Nordic brand" to be promoted in international arenas. Both developments point to a redeployment of "the Nordic" from a transnational community that the $\mathrm{NC} / \mathrm{NCM}$ was creating, to a pre-existing quality and an attribute that the NC/NCM would help Nordic actors to utilise. As such, it is not a surprise that the rhetoric of (New) Nordicness has not served to encourage Nordic cooperation.

Today, there seems to be more use for the Nordic brand than there is for the Nordic community. The purpose of this chapter is not to present a nostalgic call for a return to the past. In an age of Europeanisation and globalisation, it was arguably quite reasonable that the NC and NCM turned outwards, focusing on branding the region at a global level. The rhetoric of "the (New) Nordic" served as a way for the NC and NCM to legitimise themselves in a period when the interest in political cooperation on a Nordic level was diminishing. It becomes problematic only when branding replaces cooperation, because the first can hardly survive without the other. There a danger that the rhetoric of Nordicness loses its rhetorical force without the complex practices of comparing and contrasting the countries with each other. As such, the NC and NCM might not need a European other, but they certainly need to acknowledge their fundamental role in construing "the Nordic" through Nordic cooperation. 
